\title{
Design of Alcohol Percent Detection Devices for Food Based on Arduino Uno
}

\author{
Fera Anugrenia $^{\mathrm{a}, 1,{ }^{*}}$, Rudi Arif Candra ${ }^{\mathrm{a}, 2}$, Hasbaini $^{\mathrm{a}, 3}$, Hardisal $^{\mathrm{a}, 4}$, Fardiansyah $^{\mathrm{a}, 5}$, Irwansyah $^{\mathrm{a}, 6}$ \\ ${ }^{a}$ Departement of Computer Engineering, Polytehcnic of Aceh Selatan, Tapaktuan, 23711, Indonesia \\ *anugrenifera28@gmail.com
}

\section{ARTICLE INFO}

Article history:

Accepted

Keywords:

Sensor MQ3

Tape

Alkohol

\section{ABSTRACT}

The tape is a traditional food that is consumed by many people. Tape made using yeast by fermenting for 3-4 days covered with banana leaves to produce a sweet taste. Besides that, the tape also contains alcohol from the fermentation of yeast and rice, if you consume too much tape, the body will feel hot because it does not know what percentage of the alcohol contained in the tape. To overcome such a thing is necessary to design a measuring device for alcohol content on food tape to know the percentage of alcohol on the tape. The Arduino Uno-based Alcohol Percentage Detection Device Design Series consists of three parts: the input part, the control part, and the display part. It was created to simplify designing Alcohol Percentage Detection Devices on Food based on Arduino Uno. The MQ3 sensor is used as an input to get the alcohol percentage from the tape, Arduino Uno can be programmed in real-time, and the percentage data results will be displayed on LCD I2 Inc. Based on the test results, it can be concluded that the MQ3 sensor which functions as an input and outputs sound in the form of a buzzer. The LCD functions to display the percentage of alcohol on the tape. Tests that have been carried out get the results of the percentage of alcohol content on tape with five consecutive days of testing with an average of $22 \%, 39 \%, 46 \%, 57 \%$, and $67 \%$.

Copyright (C) 2020 Politeknik Aceh Selatan All rights reserved

\section{Introduction}

Alcohol is an organic compound or a substance that is dangerous if consumed too much. Alcohol can also be used in everyday life; alcohol is found in food, drinks, medicines, perfumes, and other solutions [1].

The tape is a traditional food consumed by many people, especially in Aceh during major holidays, such as before fasting, Eid, and reject reinforcements. Tape made using yeast by fermenting for 3-4 days covered with banana leaves to produce a sweet taste.

Besides that, the tape also contains alcohol from the fermentation of yeast and rice, if you consume too much tape, the body will feel hot because it does not know what percentage of the alcohol contained in the tape. Even people with high blood pressure will be at risk if you consume too much tape. To overcome such a thing is necessary to design a measuring device for alcohol content on food tape to know the percentage of alcohol on the tape.

Previous studies that also used Arduino devices as controllers were heart rate monitoring and mutual Koran stimulation, efficiency analysis of social media applications on mobile communication devices, and also lighting control with social media applications [2][3][4]. Measuring Alcohol Content in Drinks Using Arduino Based MQ3 Sensor [5]. Alcohol Level Test in White Rice and Cassava Tapai [6]. Detection of alcohol levels through escalation using the TGS2620 sensor [7]. This research aims to make a measuring tool using MQ3 and Arduino Uno sensors from the previous reference. An MQ3 sensor is an option because this sensor can detect alcohol directly and fast response time. The output is proportional to the alcohol received while Arduino Uno is used for the controller. 


\section{Method}

The need for hardware and software in this design include hardware that is used is a laptop with operating system Windows 10 ultimate, Arduino Uno R3 as microcontrollers, sensors MQ3 used as input, 16x2 LCD as output, Cables Jumper, Breadboard. While the software required is fritzing.0.9.0b.32.pc and Arduino 1.8.5 windows.

This design was made to simplify designing Alcohol Percentage Detection Devices for Food Based on Arduino Uno. The Design of Alcohol Percentage Detection Devices in Arduino Uno - Based Food is composed of three parts: the input using the MQ3 sensor, the control using Arduino UNO, and the display consisting of two outputs, buzzer, and LCD.

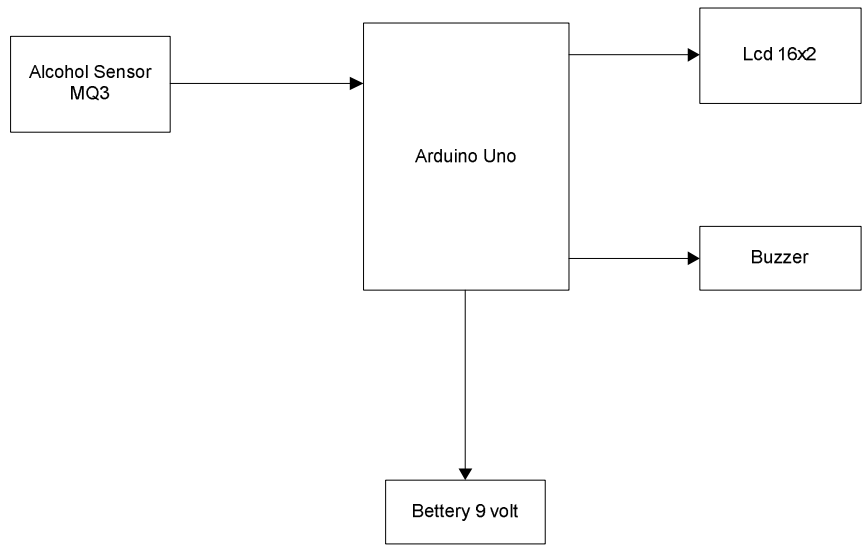

Figure 1. System Design Diagram

The following is a flowchart of the design of the workings of the Alcohol Percentage Detection Tool in which there is an Arduino-based Food to be made.

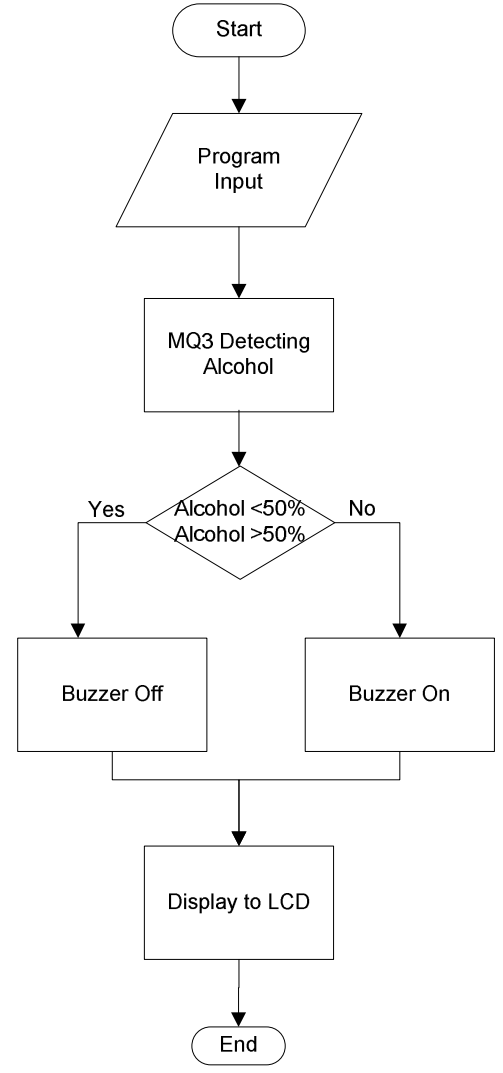

Figure 2. Program Flow Chart 


\section{Results and Discussion}

From the results of this study, several devices will be installed into a single unit, including a buzzer circuit, an MQ3 sensor circuit, an LCD circuit, and a combined circuit.

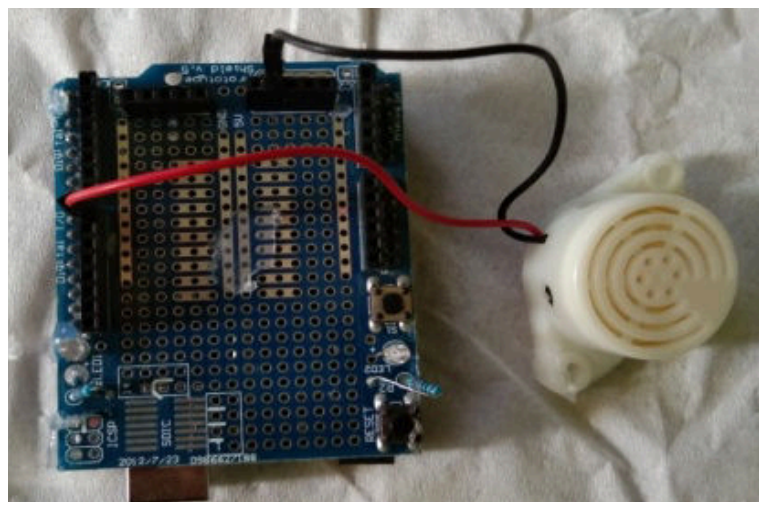

Figure 3. Buzzer Suite

In the buzzer circuit, GND Pin will be installed on the Buzzer pin connected to the GND pin on Arduino, OUT Buzzer pin on Arduino 8 pin.

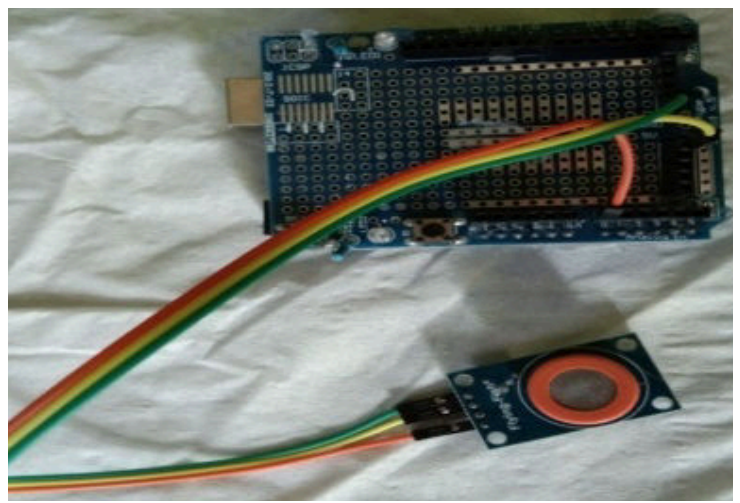

Figure 4. MQ3 series

In the $M Q 3$ circuit, the V5 pin is connected to the VCC pin on Arduino UNO, the GND pin. $M Q 3$ to the Arduino GND pin and A0 MQ3 to the Arduino A0 pin.

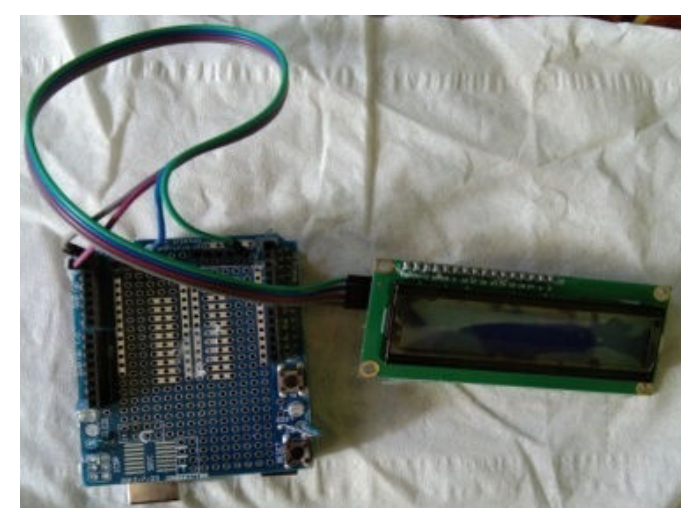

Figure 5. I2C LCD circuit

In the $12 \mathrm{C}$ LCD circuit, the I2C LCD pins that are used GND, VCC, SDA, and SCL are connected to the GND, V5, SDA, SCL pins on the Arduino Uno pin. 


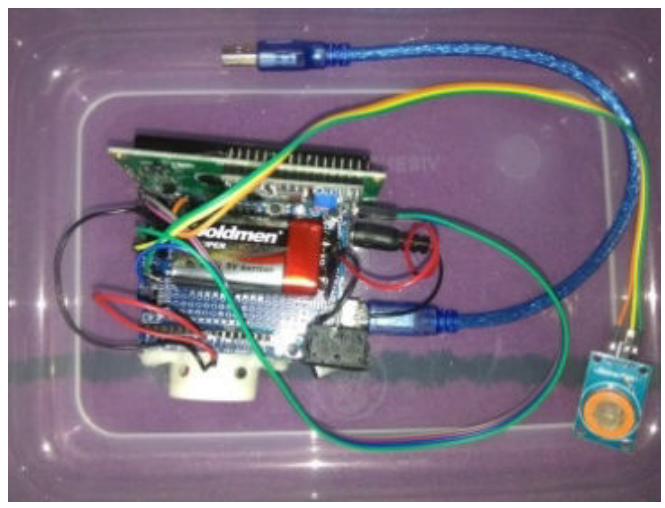

Figure 6. Alcohol Detection Circuit

In the combined circuit, the Alcohol Percentage Detection Tool for Arduino Uno-based is shown in Figure 6.

The overall display of the Alcohol Percentage in detection tool series is shown below.

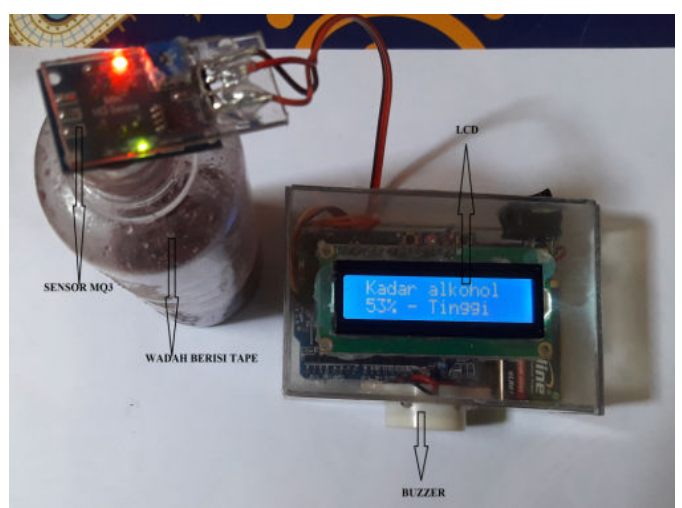

Figure 7. Alcohol Detection Test Results

Based on the Alcohol Percentage Detection Tool Series testing, the device can be seen as in Figure 7 where the tape is available in the container; then, the sensor will detect the alcohol on the tape. Then the buzzer will sound if the percentage alcohol $>50 \%$ and vice versa if the percentage of alcohol is $\leq 50 \%$ then the buzzer does not beep and display the results of the alcohol content on the LCD I2C.

After the tool is finished, it is necessary to test the tool. Where MQ3 is used as input so that the alcohol detector on the tape gets the results of the alcohol tape percentage so that the Arduino Uno can be programmed in real-time and the percentage results data can be displayed on LCD I2 Inc. The test results are made by taking data from 5 stages of testing. And at each stage of the test where the buzzer will sound if the alcohol content is $>50 \%$.

The first test and the second test were carried out after the tape was fermented for 3-4 days, which was consumed.

Based Detection Tool test Percentage of Alcohol In Food, tape first and second experimented as much as six times in one day. 
Table 1. First tape test results

\begin{tabular}{|c|c|c|c|}
\hline Days to) & Percentage yield & Buzzer & Alcohol content \\
\hline 1 & $\begin{array}{l}14 \% \\
16 \% \\
18 \% \\
20 \% \\
21 \% \\
23 \% \\
\end{array}$ & $\begin{array}{l}\text { Not ring } \\
\text { Not ring } \\
\text { Not ring } \\
\text { Not ring } \\
\text { Not ring } \\
\text { Not ring } \\
\end{array}$ & $\begin{array}{l}\text { Very low } \\
\text { Very low } \\
\text { Very low } \\
\text { Very low } \\
\text { Very low } \\
\text { Very low }\end{array}$ \\
\hline 2 & $\begin{array}{l}26 \% \\
28 \% \\
32 \% \\
36 \% \\
38 \% \\
40 \% \\
\end{array}$ & $\begin{array}{l}\text { Not ring } \\
\text { Not ring } \\
\text { Not ring } \\
\text { Not ring } \\
\text { Not ring } \\
\text { Not ring } \\
\end{array}$ & $\begin{array}{l}\text { Low } \\
\text { Low } \\
\text { Low } \\
\text { Low } \\
\text { Low } \\
\text { Low }\end{array}$ \\
\hline 3 & $\begin{array}{l}41 \% \\
43 \% \\
45 \% \\
46 \% \\
48 \% \\
49 \% \\
\end{array}$ & $\begin{array}{l}\text { Not ring } \\
\text { Not ring } \\
\text { Not ring } \\
\text { Not ring } \\
\text { Not ring } \\
\text { Not ring }\end{array}$ & $\begin{array}{l}\text { Intermediate } \\
\text { Intermediate } \\
\text { Intermediate } \\
\text { Intermediate } \\
\text { Intermediate } \\
\text { Intermediate }\end{array}$ \\
\hline 4 & $\begin{array}{l}52 \% \\
53 \% \\
55 \% \\
56 \% \\
57 \% \\
58 \% \\
\end{array}$ & $\begin{array}{l}\text { Reads } \\
\text { Reads } \\
\text { Reads } \\
\text { Reads } \\
\text { Reads } \\
\text { Reads }\end{array}$ & $\begin{array}{l}\text { High } \\
\text { High } \\
\text { High } \\
\text { High } \\
\text { High } \\
\text { High }\end{array}$ \\
\hline 5 & $\begin{array}{l}61 \% \\
62 \% \\
63 \% \\
64 \% \\
65 \% \\
66 \%\end{array}$ & $\begin{array}{l}\text { Reads } \\
\text { Reads } \\
\text { Reads } \\
\text { Reads } \\
\text { Reads } \\
\text { Reads }\end{array}$ & $\begin{array}{l}\text { Very high } \\
\text { Very high } \\
\text { Very high } \\
\text { Very high } \\
\text { Very high } \\
\text { Very high }\end{array}$ \\
\hline
\end{tabular}

Table 2. Second tape test results

\begin{tabular}{|c|c|c|c|}
\hline Days to) & Test result & Buzzer & Alcohol content \\
\hline \multirow{5}{*}{1} & $13 \%$ & Not ring & Very low \\
& $14 \%$ & Not ring & Very low \\
& $16 \%$ & Not ring & Very low \\
& $18 \%$ & Not ring & Very low \\
& $20 \%$ & Not ring & Very low \\
\hline \multirow{3}{*}{2} & $22 \%$ & Not ring & Very low \\
\hline & $26 \%$ & Not ring & Low \\
& $27 \%$ & Not ring & Low \\
& $29 \%$ & Not ring & Low \\
& $34 \%$ & Not ring & Low \\
& $36 \%$ & Not ring & Low \\
\hline \multirow{3}{*}{3} & $39 \%$ & Not ring & Low \\
\hline & $40 \%$ & Not ring & Intermediate \\
& $41 \%$ & Not ring & Intermediate \\
& $42 \%$ & Not ring & Intermediate \\
& $43 \%$ & Not ring & Intermediate \\
& $44 \%$ & Not ring & Intermediate \\
& $46 \%$ & Not ring & Intermediate \\
\hline \multirow{3}{*}{4} & $51 \%$ & Reads & High \\
& $52 \%$ & Reads & High \\
& $53 \%$ & Reads & High \\
& $55 \%$ & Reads & High \\
& $56 \%$ & Reads & High \\
\hline
\end{tabular}




\begin{tabular}{|c|c|c|c|}
\hline & $57 \%$ & Reads & High \\
\hline \multirow{3}{*}{5} & $62 \%$ & Reads & Very high \\
& $63 \%$ & Reads & Very high \\
& $64 \%$ & Reads & Very high \\
& $65 \%$ & Reads & Very high \\
& $66 \%$ & Reads & Very high \\
\hline
\end{tabular}

From the 2 tests above it can be concluded that on the first day tape the average alcohol content is $14,16,18,20,21,23-13,14,16,18,20,22 \%$. Tape day 2 the average alcohol content of 26, 28, 32, $36,38,40-26,27,29,34,36,39 \%$. Tape day 3 the average alcohol content of $41,43,45,46,48$, $49-40,41,42,43,44,46 \%$. Tape day 4 the average alcohol content of 52, 53, 55, 56, 57, 58-51, 52, $53,55,56,57 \%$ Tape day 5 the average alcohol content of $61,62,63,64,65,66-62,63,64,65,66$, $67 \%$.

\section{Conclusion}

After doing the design and realization of the Alcohol Percentage Detection Tool and then testing the tool as a whole, it can be concluded:

The tool that has been made can work well as expected. Where MQ3 that functions as an input and output in the form of sound on the buzzer. The LCD functions as showing the percentage of alcohol on the tape. And Arduino Uno R3, which is used as the central controller of the tool can work in running programs or commands given.

The above test can be concluded that on the first day tape average alcohol content of 14, 16, $18,20,21,23-13,14,16,18,20,22 \%$. Tape day 2 the average alcohol content of $26,28,32,36,38$, $40-26,27,29,34,36,39 \%$. Tape day 3 the average alcohol content of $41,43,45,46,48,49-40,41$, $42,43,44,46 \%$. 4th day tape average womb

alcohol as much as $52,53,55,56,57,58-51,52,53,55,56,57 \%$ Tape day 5 the average alcohol content of $61,62,63,64,65,65,66-62,63,64,65,66,67 \%$.

\section{References}

[1] I. G. Surya Merta, I. G. A. Widagda, and I. B. Alit Paramarta, "Perancangan Alat Ukur Kadar Alkohol Menggunakan Sensor Mq-3 Berbasis Mikrokontroler Atmega16," Bul. Fis., vol. 18, no. 2, p. 74, 2017, doi: 10.24843/bf.2017.v18.i02.p06.

[2] D. N. Ilham, H. Hardisal, B. Balkhaya, R. A. Candra, and E. Sipahutar, "Heart Rate Monitoring and Stimulation with the Internet of Thing-Based (IoT) Alquran Recitation," SinkrOn, vol. 4, no. 1, p. 221, 2019, doi: 10.33395/sinkron.v4i1.10392.

[3] R. A. Candra, D. N. Ilham, H. Hardisal, and S. Sriwahyuni, "Light Control Design by Using Social Media Telegram Applications Based on Internet Of Things (IOT)," SinkrOn, vol. 3, no. 2 , p. 200, 2019, doi: 10.33395/sinkron.v3i2.10094.

[4] R. A. Candra and D. N. Ilham, "Analisis Efisiensi Energi Pada Aplikasi Media Sosial Menggunakan Perangkat Komunikasi Bergerak,” vol. 9, pp. 125-131, 2019.

[5] A. V Simanjuntak, "Alat Ukur Kadar Alkohol pada Minuman Beralkohol Menggunakan Sensor MQ3 Berbasis Arduino,” Univ. Sumatera Utara, pp. 1-68, 2017.

[6] Z. Berlian et al., "Uji Kadar Alkohol Pada Tapai Ketan Putih Dan Singkong Melalui Fermentasi Dengan Dosis Ragi Yang Berbeda," J. Biota, vol. 2, no. 1, pp. 106-111, 2016. 
[7] N. M. Tulung, "Rancang Bangun Alat Pendeteksi Kadar Alkohol Melalui Ekhalasi Menggunakan Sensor Tgs2620 Berbasis Mikrokontroler Arduino Uno," J. Tek. Elektro dan Komput., vol. 4, no. 7, pp. 15-24, 2015, doi: 10.35793/jtek.4.7.2015.10590. 